\title{
From proto-missional to mega-church: A critique of ecclesial 'growth' in Korea
}

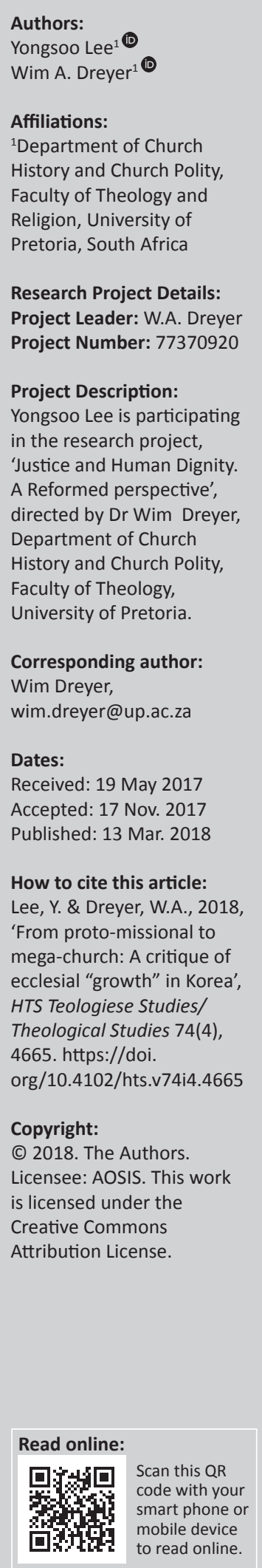

In the last couple of decades, the Korean church experienced a loss of credibility as well as a decrease in membership. The premise of this contribution is that the mega-church phenomenon in Korea contributed to this state of affairs. Many Korean churches, influenced by dramatic sociopolitical and economic changes, developed a distorted understanding of its nature and mission. Korean churches began to compete against each other to grow bigger. An institutional ecclesiology and ecclesiocentric understanding of mission formed the basis of this endeavour. To counter this tendency, some churches turned to missional ecclesiology to facilitate the reformation of the Korean church. According to empirical data, Korean society rates megachurches negatively while they evaluate missional churches positively. This provided further impetus for the current emerging missional movement in Korea.

\section{Introduction}

Missional ecclesiology understands the church as part of the missio Dei. Missional ecclesiology does not understand mission or the calling of the church as limited to the conversion of an individual nor the obligation to gather the church. Being church and mission is the participation in the Triune God's redemption of creation (Engelsviken 2009:482). Therefore, the essence of being church is to be found in its participation in God's mission to the world (Dreyer 2013:4; Van Gelder \& Zscheile 2011:149). In this understanding, the church, not only the clergy but all members of the church, ought to embody the mission of Jesus, proclaiming the kingdom of God through their words and deeds in any given context, as a faithful instrument of God. In missional ecclesiology, the church understands itself not as a building or institution but as a community of witnesses (Hooker 2008:1) with a theocentric understanding of mission, characterised by incarnational and transformational discipleship (The Archbishop's Council 2004:81-82).

Although the early Korean church did not have knowledge of 'missional ecclesiology', their faith and attitude to Christian life clearly displayed the characteristics of a missional church. They emphasised the propagation of the gospel and living according to the word of God as a community of disciples. Although they experienced rapid growth, they did not get stuck in church building but rather focused on a life of worshiping whenever they gathered at the houses of volunteer believers (Choi 2015:90). During the dark age of Korea, the Japanese colonial era, the Korean church became the hope of the nation in leading a non-violent independence movement and a national enlightenment. When they were challenged to deny Christ Jesus and bow down before Japanese national gods, the early Korean church demonstrated to the world the commitment of ordinary believers to the kingdom of God, through resistance to the point of death without compromise. As a prototype missional church, the early Korean church gained the respect of the Korean society.

However, today, Korean society rates the Korean church as spiritually and morally bankrupt. This negative evaluation from the society has had great influence on the decrease of the membership of the Korean church. The Korean National Statistical Office conducted a Population and Housing Census in 2005 and announced that the overall number of Christians in South Korea had reduced by $1.6 \%$ over the previous 10 years, and now the situation has deteriorated even further (Kil 2008:1-2). Korea received the gospel about 130 years ago, but now the Korean church has fallen from being the light of the nation to a marginalised troublesome ghetto. After extensive empirical research to figure out why the Korean church has been in such a crisis, Shin (in Kang et al. 2013:228-229) argues that the mega-church phenomenon lies at the heart of the crisis. With growth as its sole aim, a church easily falls into an institutional (building and clergy-centred) ecclesiology (Lee 2014:55) and an ecclesiocentric missiology in which a church can select when, where and how to do its missionary

Note: This article represents a reworked version of aspects from the PhD thesis of Yongsoo Lee, titled, "From proto-missional to mega-church: a critique of ecclesial "growth" in Korea', in the Department of Church History and Church Polity, University of Pretoria, with Dr Wim A. Dreyer as supervisor. 
work. Mission, with power and resources generated through size and membership (Hendriks 2007:1006), became an ecclesial enterprise to grow numbers and income.

According to Karl Barth (see Dreyer 2015:1-2), the real crisis of the church is more than external circumstances such as the decline of membership and financial hardship. It would rather be found internally, in that the church is unable to be a true church, untrue to its own nature and calling, not doing what it is supposed to do. Listening to Barth, this article suggests that missional ecclesiology could assist the Korean church to restore its lost integrity, to be what it is supposed to be (Dreyer 2015:8).

This article employs a multidisciplinary approach which looks at the Korean church from hermeneutical, historical, empirical and strategic perspectives. The purpose of this approach is to come to a better understanding of the church and make some suggestions for the way forward.

\section{Hermeneutical perspective}

The Bible is the normative source for understanding the nature and mission of the church (The World Council of Churches 2005:6; Wright 2010:20). Therefore, it is of the utmost importance to examine how the Bible speaks about the nature and mission of the church. The metanarrative of the Bible is God's mission which is grounded in the very nature of God (Bauckham 2004:92; Wright 2006:64). The mission of God is disclosed through the four major themes of Creation-Fall-RedemptionNew Creation (Wright 2010:39) as explained below:

Creation: God created the whole universe and established his kingdom, so that all creatures could glorify and enjoy Him forever. The sovereign God decided to entrust man with ruling the created world in obedience to God. This delegation was fulfilled by Jesus Christ and inherited by the church. The nature of the church, therefore, originates from God's missional nature and the church, in its mission, has to reflect the attributes of the Trinitarian God such as love.

Fall: God's creation was (and is) affected by the rebellious sin of humanity. Despite the fall, God in his sincerity and consistency never stopped his redemptive mission through his people from Abraham to the spiritual offspring of Abraham (the church). The church, therefore, as the community that found peace with God, is called to take part in the mission of God by following the guidance of the Holy Spirit in God's original good design to restore the present fallen realities in the world and by unmasking the destructive forces against the kingdom of God.

Redemption: God sent his Son through whom all the people could be reconciled with him and restored to continue the first commission (the cultural mandate). The church as a community of disciples has to focus on making the mission of God known to the world by bearing witness and inviting people in the world to become reconciled to the living and true God with an incarnational life as Jesus demonstrated through his public life.
New Creation: The church is called in these last days to witness to the kingdom of God by proclaiming the gospel with words and deeds. The church is a foretaste of the New Jerusalem. To sincerely respond to this call, the church becomes an eschatological alternative community living by the hope of ruling together with the Lord forever, even to the extent of being martyrs.

In this flow of the redemptive metanarration, it is clearly shown that the church as the restored people was born to be a witnessing community and the mission of the church is to be participating in the redemptive mission of God. This is also supported by the most important metaphors of the Bible for the church: The people of God, the body of Christ, the communion of the saints and the temple of the Holy Spirit (World Council of Churches 2005:6).

The church as the people of God whose citizenship is in heaven yet living on earth (Phlp 3:19-20) represents the reign of God to the world by obeying the law of God. Therefore, it is inherently political and it lets the world experience something of the unique character of God's kingdom such as being a united but diverse as well as a non-violent community.

As the body of Christ, the church acts and lives and speaks like him (Dreyer 2016:4). Following where Jesus is heading, they marginalise themselves to be with the vulnerable to rejoice and mourn together ( $\operatorname{Rm} 12: 15)$. Being a community without power means the church stands over and against the world that seeks power and is ruled by a winner takes all system.

The church as the communion of the saints is called to represent Jesus in its service, to be Jesus to others. They are sent to live out the love of Jesus through their transformed lives in its individual and communal dimensions, which demonstrate to the world genuine reconciled fellowship.

The church as the temple of the Holy Spirit is holy and is to be holy. Although its holiness does not lie in being without sin, but through the indwelling of the Holy Spirit, it is called to witness to the kingdom of God to the world by embodying the holiness of God through its holy life dedicated to God and distinguishable from other communities or peoples through their unselfish love (Dreyer 2015:4).

The biblical narration consistently teaches that for the church to be the church of Jesus Christ is to stay with its nature as a witnessing community and to take part in the mission of God to restore the kingdom of God. This is the core of missional ecclesiology. Accepting the missional nature of the church is a prerequisite to enable and activate the church to live with integrity, in other words, to be true to its own nature and mission.

It is necessary to establish the scope of missional ecclesiology as there has been tension between two extreme views in the Korean churches on missional ecclesiology, rooted in different understandings of the missio Dei. While one group attempts to categorically refuse missional ecclesiology, insisting that it provokes anarchy in the church, the other group argues 
that with it the church has to start a counter-movement to dismantle and revise the existing churches. This article disagrees with both extreme views on missional ecclesiology. Rather, God intends to restore his creation by sending the church, which is reconciled with him through the redemptive ministry of Jesus and is playing the role of his witness to the world through the guidance and empowerment of the Holy Spirit, in which the Triune God becomes the subject and the church becomes his instrument (Chung 2007:233). This does not imply anarchy or the destruction of ecclesial structures but rather ensures the transformation of our understanding of the church, which in itself will lead to the reformation of the church.

\section{Historical perspective}

During the previous 130 years of its history, the Korean church carried out its mission in different ways or modes of being church: The apostolic and post-apostolic mode (18791945), the advance and triumph of the pseudo-Christendom mode (1945-2000) and the missional mode (past $20+$ years) (Choi 2015:29).

In the apostolic and post-apostolic mode, the early Korean church, although it did not know the present missional ecclesiology, was inherently a missional church with its biblical characteristics of missional ecclesiology, a protomissional church. The early Korean church from its initial stage spontaneously participated in God's mission to restore his kingdom on Korean soil, testified to the gospel by their changed words and deeds as a disciple community wherever they were sent. Their spontaneity was expressed through the three-self principles as follows:

Self-propagation: The early Korean Christians with the joy of salvation voluntarily testified to the gospel by their changed words and deeds. In this way, the indigenous Korean churches were spontaneously established.

Self-government: They did not get stuck in church building endeavours but governed the church by themselves without the clergy.

Self-support: They could stand alone and help other churches by giving beyond their ability like the Macedonian churches (2 Cor 8:3).

This missional spontaneity with the three-self principles was fostered and facilitated with the help of the Western missionaries who focused on teaching the Bible to the Korean Christians. As Clark (1994:320-324) pointed out, the essence of the three-self principles was Bible study, and it brought about actualisation of the principle.

In their mission, the Korean church avoided the present topdown, power-based imperialistic mission but pursued an incarnational mission, giving up all kinds of privileges, positions, titles and authority, to be present in the proximity of the marginalised. Through this humble (powerless) service, the early Korean church made genuine relationships with the Korean people and the gospel was proclaimed through the relationships. By carrying out their mission, the early Korean church did not compete for quantitative growth of individual believers and churches but worked together to expand the kingdom of God (Park 2003:98).

The missional ethos and praxis of the early Korean church continued even during its settlement stage through the renewing power of the Holy Spirit. Many of the Korean people indulged in alcohol, drugs, prostitution and gambling, living without hope when the imperial Japan usurped the police authority and the sovereignty of the state in 1905 and 1910, respectively (Kim \& Roh 2007:37-38). In this difficult environment, the early Korean church led the repentance movement and that ignited the 'Pyongyang Great Awakening' in 1907. With remarkable manifestations of the Holy Spirit in the revival movements, the early Korean church could avoid being institutionalised and built peace in the Korean society between ethnics, genders and social ranks that led to the transformation of distorted and unfair feudalistic social structures (Kim \& Roh 2007:125).

Throughout the national hardship during the Japanese colonisation period, the Korean church was with the Korean people to share their sufferings and fought together to seek justice. Although their blood was shed for the people, they manifested God's just ruling by their non-violent movement such as the First of March Independence Movement of 1919. Against life-threatening persecutions to deny Jesus and to compromise with the worldly power, the early Korean church proved the value of the truth they spread and displayed their true hope of eternal life by obeying Christ to the point of martyrdom. The early Korean church rapidly grew in numbers though they did not aim to grow bigger by attracting people to come to church buildings. When they held on to what they already were, the people of God, the body of Christ and the temple of God (Dreyer 2015:4), as a proto-missional church, they became attractive to the Korean people, and this resulted in their numerical growth.

The integrity of the Korean church in the apostolic mode has, however, been lost in the advance and triumph of the pseudo-Christendom mode. After the liberation from Japanese colonisation and the Korean War, the Korean church came to enjoy a national religion-like status through a close relationship with the government and thereafter its mission became focused on numerical growth of individual churches through the influence of the Pseudo-Christendom understanding of the nature and mission of the church, in which territorial expansion of the institutional church by physical might was regarded as the extension of the kingdom of God (Chung 2014:44). This became intense owing to the prosperity theology and consumerism affected by the radical modernisation, characterised by industrialisation and urbanisation and economic development. The mission of the church in the pseudo-Christendom mode was led by a handful of mega-churches in Korea as they were regarded as examples of a successful church growth model with their size 
and influence (Park 2008:30). This drove the Korean church into the mega-church phenomenon. In the competition to attract more people to their own church buildings to grow to be another mega-church, churches in Korea came to have institutional and a building-focused ecclesiology and clergycentred organisational structure as well as a programmeoriented ecclesiocentric missiology. Although serious competitions for numerical growth led to a dramatic growth of the Korean church in membership, it resulted in 'its inability to be church - sometimes not even conscious of what the church is or should be and sometimes deliberately ignoring it for personal gain' (Dreyer 2015:4). As Dreyer (2015:4) argues, 'When the church dilutes into mere human activity, it is not church anymore' and that loss of integrity and identity of the church is the reason for the crisis in the Korean church.

As the postmodern culture has been prevalent in Korea since the early 1990s, the Korean church has lost its privileged status and has become marginalised by the Post-Christendom of the postmodern world (Park 2008:31). The Korean church with its fossilised intuitional forms under the influence of the mega-church phenomenon has lost its missional dynamics as an instrument for God's mission and has failed to properly react to rapidly changing contexts. Moral and financial corruption of the senior pastors of mega-churches caused by secularisation coupled with the aforesaid failures accelerated the marginalisation of the Korean church in the Korean society. With crisis awareness, since the early 2000s, there have been some churches struggling with ontological selfquestions about the biblical nature and mission of the church. It has led to the introduction of the missional ecclesiology from the Western church through conversations and ventures between those churches to apply the missional ecclesiology to their ministries and church plantings, which has become an emerging missional movement (Choi 2009:380).

\section{Empirical perspective}

Empirical data collected through interviews and analysis of media reports (see Lee 2017), detected and presented in concrete ways how different understandings of mission and church affects the ministries and structures of the particular churches and how the general perception of the Korean society towards the ministerial manifestations of the Korean mega-churches and missional churches represented by the sample churches are. This should provide an impetus for the Korean church to grow in biblical ideals.

Two Korean mega-churches and two missional churches were looked at as case studies. They were selected not because of their size of congregations that gather on Sunday mornings but because of certainty of their ministerial manifestations which display the characteristics of the missional movement and the mega-church phenomenon. One of the missional churches was a mega-church in size but could be a missional church with its missional characteristics.

The mega-church phenomenon has its own missiological and ecclesiological perspectives and they are obviously from the two mega-churches, the Immanuel Church and the Jeja Church. The Immanuel Church is located in Seoul, the capital city of South Korea, and is well known as a Korean crystal church as its church building was benchmarked Robert $\mathrm{H}$. Schuller's Crystal Cathedral in the United States. It is one of the representative churches in the Methodist denomination with about 20000 members but has been embroiled in conflicts for several years owing to nepotism. The former senior pastor replaced himself with his son in 2013 in controversial ways. The Jeja Church is located in Mok-dong, a neighbourhood in Seoul. It has around 10000 members and is widely renowned for its resplendent building and discipleship training programmes called D.N.A. Although the church has carried out some charity ministries, it is being shunned by the Korean society as the senior pastor's embezzlement of public money was revealed in 2013.

Both churches understand that the growth of individual churches is the expansion of the kingdom of God and that it must be achieved by all means even through the power and material obtained from growth. For the sake of effective and efficient numerical church growth, both churches have splendid church buildings with user-friendly facilities to attract more people. They also display the ministerial and structural characteristics of the churches of the mega-church phenomenon such as church growth programme-based ministries with prosperous messages trying to comfort their congregations and hierarchical triangular structures strictly centred on the senior pastors. Although both mega-churches emphasised discipleship training, it is rather raising workers productively to run various church growth programmes within the church buildings, obeying the senior pastors, than making disciples of Jesus who live out the gospel outside the church buildings through their holy words and deeds.

In the mainstream of the mega-church phenomenon, there have been church reforming movements to restore its missional ethos and praxis under the common awareness of the crisis that 'the church is increasingly out of tune with contemporary culture, and that unless it comes to terms with change, it faces extinction'. (Stott 2007:12). The missional church movement has its understandings of the nature of the church and mission on the basis of the missional ecclesiology. It can clearly be seen from the Bundang Woori Church and the Pillar of Fire Church.

The Bundang Woori Church was founded in the Bundang metropolitan area, established about 10 years ago. Since its inception, it has been renting a high school gym instead of having its own building. Though its membership grew very fast and reached about 20000 registered church members, it proclaimed a movement called 'Dispatching 10000 church members' in 2012. Since then, the church started downsizing and has sent many well-trained members to small and weak churches in their vicinity. The Pillar of Fire Church is situated at Oido in the vicinity of a large industrial complex where a number of foreign labourers and malfunctioning families stay. The church runs a small snack bar, named 'Oh Dduk Yi 
$\mathrm{Uh}^{\prime}$, meaning five loaves of bread and two fishes. It is situated in front of a primary school during the week days and gathers every Sunday as a church at the same place. It tries to propagate the gospel naturally by being a friend of children from malfunctioning families after school. The church also runs a second-hand clothes shop named 'Flowing \#' for the foreign labourers and has a good reputation with the neighbouring local community.

Both churches recognise their calling as an instrument of the mission of God to demonstrate the kingdom of God where they are located by reincarnating (embodying) Jesus through their spontaneous serving and sharing ministries in incarnational ways, in order to satisfy real needs of the local people, rather than to run various church-oriented programmes to attract more people to the church, pursuing quantitative growth. To carry out such ministries, their organisations form non-hierarchical relationship-centred structures rather than a one-dimensional top-down triangular hierarchy optimised for church growth and management.

Towards ministerial manifestations of the churches belonging to the mega-church phenomenon and the missional church movement, the Korean society has different general perceptions. On the one hand, the churches with the megachurch's understanding and practise of being church receive negative social evaluation owing to their severe competition to attract more people to their luxurious church buildings and material and power-oriented programme-centred missions irrelevant to the local society. Ethical failures of the senior pastors of mega-churches are recognised as a serious social problem. The Korean church is trampled by society like the salt that has lost its saltiness (Mt 5:13) and has become marginalised. On the other hand, the churches with the missional church's understanding and practise of being church receive a favourable social evaluation with their social contribution ministries and fresh approaches to the symbiosis and mutual growth of churches. The Korean society expects these aspects to bring about positive changes in the Korean church. This gives an impetus for the Korean church to let the missional church movements continue and prevail as the biblical way to being a church.

\section{Strategic perspective}

The Korean church under the influence of the mega-church phenomenon with its Christendom-like understanding of the nature and mission of the church has focused on running programmes optimised for its numerical growth rather than being incarnational to its local context. It also has become secularised by pursuing consumerist ideals like a shopping mall and has continued with competition and division for the growth of individual churches, neglecting the unity as the one body of Christ Jesus. Being influenced by the megachurch phenomenon, it lost its biblical understanding of mission and of the church. In this way, the Korean church has marginalised itself in the Korean society. In these crises, the Korean church has been challenged to enter a process of radical reformation (Dreyer 2013:3). Choi (2015:176) says that although many people want the reformation of the Korean church, it does not happen because of changing structures and laws. It only happens when the church becomes a true church. To this effect Park (2013:115) argues that the Korean church has to restore its missional integrity before doing something for the world.

Although the Korean church, by following the megachurch phenomenon, has incurred crisis situations, its marginalised position in the society can be an opportunity. In terms of its marginal status in society, the contemporary Korean church is in the same condition as the early Korean church, though in a different context, and has shifted itself to the margins of society. Under their marginalised conditions, the early Korean church followed the scriptural guidelines with its proto-missional understanding of the nature and mission of the church, transcending its contextual challenges. As with the early Korean church, the marginal status of the present Korean church can be an opportunity to restore its missional ethos and praxis by reconnecting with the Bible, as the New Testament is a collection of missionary documents written by Christians living on the margins of their culture, in a missionary situation (Chester \& Timmis 2011:loc 76-78).

\section{According to Dreyer (2016):}

Wherever there is a lack of theological depth in our ecclesiology, it leads to poor governance, a deathly silence on injustice, tolerance of corruption, materialism and a general loss of integrity and credibility. (p. 24)

Therefore, it is of the utmost importance that the emerging missional movement in Korea is to be a reforming movement that resists the strong tendency to pursue the ways of the mega-church phenomenon and restores the biblical missional nature and practice of the church that the early Korean church had earlier. Some strategic ways can be proposed for the Korean church in its crisis to restore its biblical integrity on the basis of the foregoing hermeneutical, historical and empirical researches. To restore the missional dynamics of the early Korean church, the contemporary missional movement is to apply and practice the missional ecclesiology that presents the four marks of the church. As they are derived from the attributes of the Trinitarian God, the four marks are correlational and can be rearranged centred on the church's apostolic missional nature, thus ensuring apostolic catholicity, apostolic holiness and apostolic unity (Guder 2015:87).

This strategic approach does not mean quick-fix solutions or more programmes but means that we need to look at ways in which the church can become what it already is - the people of God, the body of Christ, the communion of the Saints and the temple of the Holy Spirit - the restoration of its integrity (Dreyer 2016:1). To restore its missional ethos and praxis, the Korean church is to be a community that manifests the attributes of God to the Korean society with its apostolic catholicity, holiness and unity as follows: 
Apostolic Catholicity: The mission of the Korean church is not to be imperialistic but indigenised and contextualised to be incarnational. For that, the churches in Korea are to relocate themselves to be with the marginalised vulnerable. Social participation to promote peace and reconciliation is to be considered to be their primary mission. They are to be a blessing by redistributing of what they are given by God, to the people in need.

Apostolic Holiness: To make the invisible God's ruling visible, the church itself is to live with a deep consciousness that it is more than just another social organisation or human institution as a community created by the Holy Spirit (Van Gelder 2000:116-117) to serve the world as Christ's letter. To carry out its mission, the Korean church is to be a countercultural community, following the way of the cross by radical discipleship not only within a church but also outside the church through a transformational leadership development. Its leadership structure is also to be equal and nondiscriminatory based on the spiritual gifts given to all members of the church that differs from the one of the world.

Apostolic Unity: The Korean church as the body of Christ should bear witness to the world that Christ is the only Head of the church, through their communal life within an individual church, in a congregation and between local churches. Substantial solidarity and cooperation like financial supports and spontaneous size limit of churches for intimate relationships and mutual growth can possibly facilitate communal fellowship.

\section{Conclusion}

This article argued that missional ecclesiology could assist the Korean church to restore its true nature and mission, to break through the integrity crisis it is confronted with. Although the Korean church grew as a prototype of a missional church in its initial period, it has lost its missional ethos and praxis in the rapid modernisation of Korea, by indulging in a growth-oriented ideology led by some mega-churches. The Korean church with the mega-church phenomenon's understanding of the church and mission has lost its power to grow and has become marginalised with negative evaluations of it by the Korean society. With crisis awareness, there have been some conversations and ventures among the Korean churches to return to be missional churches with a missional ecclesiology. Those attempts are being praised by the Korean society. The Korean church is therefore to continue and develop its missional movement to restore its biblical integrity.

As Dreyer (2016:17) says, 'being church with integrity ... is not a simple matter, but requires continual reformation and transformation'. What Pascal (Kreeft 1993:321) said is worthy of note if a church wants to live missionaly: 'The least movement affects all nature; the entire sea changes because of a rock. Thus, in grace, the least action affects everything by its consequences'.

\section{Acknowledgements Competing interests}

The authors declare that they have no financial or personal relationships which may have inappropriately influenced them in writing this article.

\section{Authors' contribution}

This article was submitted by Y.L. as part of the requirements for the PhD degree (Church History) at the University of Pretoria under the supervision of W.A.D.

\section{References}

Bauckham, R., 2004, The Bible and mission: Christian mission in a postmodern world Baker, Grand Rapids, MI.

Chester, T. \& Timmis, S., 2011, Everyday church: Mission by being good neighbours, Kindle edn., IVP, Nottingham.

Choi, D.K., 2009, 'Challenges of the postmodern Korean culture and tasks of the Korean church', Theology and Praxis, September, 349-384.

Choi, D.K., 2015, Early Korean church and its church planting ministries from a perspective of missional church, Christian Literature Centre, Seoul.

Chung, H.S., 2014, 'A comparative study on church and state relations in the thoughts of St. Augustine, Martin Luther and Karl Barth', MA dissertation, Dept. of Theology, Hansin University.

Chung, S.H., 2007, 'The origin of the missio Dei and its implication to missional ecclesiology: The critical reflection of Willingen IMC (1952)', Mission and Theology, August, 185-212.

Clark, C.A., 1994, Korean church and Nevius methods, The Christian Literature Society of Korea, Seoul.

Dreyer, W.A., 2013, 'Missional ecclesiology as basis for a new church order: A case study', HTS Theological Studies 69(1), Art. \#1368, 1-5. https://doi.org/10.4102/ hts.v69i1.1368

Dreyer, W.A., 2015, 'The real crisis of the church', HTS Theological Studies 71(3), Art. \#2822, 1-5. https://doi.org/10.4102/hts.v71i3.2822

Dreyer, W.A., 2016, 'Church, mission and ethics. Being church with integrity', HTS Theological Studies 72(1), a3163. https://doi.org/10.4102/hts.v72i1.3163

Engelsviken, T., 2009, 'Missio Dei: The understanding and misunderstanding of a theological concept in European churches and missiology', International Review of Mission 92(367), 481-497. https://doi.org/10.1111/j.1758-6631.2003. tb00424.x

Guder, D.L., 2015, Called to witness: Doing missional theology, Eerdmans, Grand Rapids, MI.

Hendriks, H.J., 2007, 'Missional theology and social development', HTS Theological Studies 63(3), 999-1016. https://doi.org/10.4102/hts.v63i3.244

Hooker, P., 2008, What is missional ecclesiology?, viewed 09 March 2016, from http:// www.negapby.org/missionalecc.pdf

Kang, Y.A., Koo, G.H., Kwon, Y.K., Kim, G.J., Kim, S.Y., Kim, E.G. et al., 2015, The Korean church, seeking the way of reformation: 20 essential assignments to be the new Korean church, Holy Wave Plus, Seoul.

Kil, C.J., 2008, 'Church growth through adapting the G-12 cell model at Hosanna Community Church, Goyang, Korea', PhD thesis, Dept. of Theology, Regent University.

Kim, S.J. \& Roh, N.D., 2007, The Korean church and the great awakening movement, Qumram, Seoul.

Kreeft, P., 1993, Christianity for modern pagans: Pascal's Pensées, Ignatius, San Francisco, CA.

Lee, Y., 2017, 'From Proto-missional to megachurch: A practical-ecclesiological critique of church "growth in Korea"', PhD dissertation, Faculty of Theology, University of Pretoria.

Lee, Y.S., 2014, 'A Korean perspective on megachurches as missional churches', MA dissertation, Dept. of Theology, Pretoria University.

Park, C.S., 2003, Protestantism and politics in Korea, University of Washington Press, Seattle, WA.

Park, H.S., 2008, 'A study of missional structures for the Korean church for its postmodern context', PhD thesis, Dept. of Intercultural Studies, Fuller Theological Seminary.

Park, Y.D., 2013, A twisted face of the Korean Church, IVP, Seoul.

Stott, J.R.W., 2007, The living church: Convictions of a lifelong pastor, IVP, Downers Grove, IL.

The Archbishop's Council, 2004, Mission-shaped church, Church House, London. 
The World Council of Churches, 2005, The nature \& mission of the church: A stage on the way to a common statement, WCC, Geneva.

Van Gelder, C., 2000, The essence of the church: A community created by the Spirit, Baker, Grand Rapids, MI.

Van Gelder, C. \& Zscheile, D.J., 2011, The missional church in perspective: Mapping trends and shaping the conversation, Baker, Grand Rapids, MI.
World Council of Churches, 2005, The nature \& mission of the church: A stage on the way to a common statement, WCC, Geneva.

Wright, C.J.H., 2006, The mission of God: Unlocking the Bible's grand narrative, IVP, Downers Grove, IL.

Wright, C.J.H., 2010, The mission of God's people: A Biblical theology of the Christ's mission, Zondervan, Grand Rapids, MI. 